\title{
Reactions and Resistance Status of Red Rice Genotypes against Stem Borer and Gall Midge under Different Agro-Climatic Zones of Chhattisgarh, India
}

\author{
Mangla Parikh ${ }^{1 *}$, Bhawana Sharma ${ }^{1}$, Sandeep Bhandarkar ${ }^{1}$, \\ Om Narayan Verma ${ }^{2}$ and G.C. Ojha ${ }^{1}$ \\ ${ }^{1}$ Department of Genetics and Plant Breeding, College of Agriculture, Indira Gandhi Krishi \\ Vishwavidyalaya, Raipur, Chhattisgarh 492007, India \\ ${ }^{2}$ Sant Kabir College of Agriculture and Research Station, Kawardha, Indira Gandhi Krishi \\ Vishwavidyalaya, Raipur, Chhattisgarh 492007, India \\ *Corresponding author
}

\begin{tabular}{|c|c|}
\hline & A B S T R A C T \\
\hline Keywords & \multirow{4}{*}{$\begin{array}{l}\text { Fifteen red rice genotypes were screened for resistance to rice stem borer and } \\
\text { gallmidge at two agro-climatic zone of Chhattisgarh region during Kharif } 2016 \\
\text { along with two commercial red rice Kerala varieties. All the genotypes were } \\
\text { evaluated under natural conditions. The genotype Dubraj (D: 1251) was found to } \\
\text { be resistant with ' } 1 \text { ' scale for stem borer and genotype Shrikamal (S: } 660 \text { I) was } \\
\text { found moderately resistant with ' } 3 \text { ' scale at Northern Hills zone i.e. Ambikapur. In } \\
\text { Bastar Plateau zone i.e. Jagdalpur, most of the genotypes were found with '0' } \\
\text { scale having no symptoms of stem borer and gallmidge. These resistant sources } \\
\text { found in the trial can further be exploited in breeding programme for the } \\
\text { development of stem borer and gallmidge resistant commercial cultivars by } \\
\text { determining their genetics. }\end{array}$} \\
\hline $\begin{array}{l}\text { Germplasm, Red } \\
\text { rice, Stem borer, } \\
\text { Gall midge, } \\
\text { Resistance. }\end{array}$ & \\
\hline Articl & \\
\hline $\begin{array}{l}\text { Accepted: } \\
\text { 17 September } 2017 \\
\text { Available Online: } \\
10 \text { October } 2017\end{array}$ & \\
\hline
\end{tabular}

\section{Introduction}

Rice (Oryza sativa L.) is the world's single most important crop belonging tothe family Graminae or Poaceae.

It is one of the most significant cereals and is the staple food for more than 2 billion people Total area under rice in India is 46.6 million hectare with annual production of 106.6 million tonnes and productivity is 2.46 tonnes /ha(Anonymous, 2014). Due to its wide geographical spread and long history of domestication, there exists high variability among rice cultivars throughout the tropics.
Chhattisgarh state is known as "rice bowl" of India which acre age 3.67 million hectare with a total production and productivity of 6.7 million tonnes and 2.02 tonnes /ha, respectively (Anonymous, 2015).In Chhattisgarh region, various rice pests are causing losses up to 20 per cent every year. The major insect pests of rice in Chhattisgarh are Yellow stem borer (YSB), Brown plant hopper (BPH), Green leafhopper (GLH), White backed plant hopper (WBPH), Leaf folder (LF), Gall midge (GM), Case worm (CW) and Gundhi bug (GB) etc. 
The main emphasis of rice varietal improvement in all countries and in international research institutions has been on increasing the production per unit area, followed by imparting resistance against biotic stresses, and finally on cooking and grain quality. In white rice varietal improvement programs, red rice varieties have proved to be useful donors for sources of resistance/tolerance to many stress environments and for imparting resistance to important pests and diseases. Redland races such as Ptb 18, Ptb 19, Ptb 21, and Ptb 33, with broad-spectrum resistance have been used in resistance breeding programs all over the world. Search for appropriate donor's resistance to both biotic and abiotic stresses is a continuous process because the resistance is not long lasting, and due to high pathogen plasticity in the fields makes single resistance gene breakdown after three to five years of the cultivar release. Hence, development of broad spectrum and durable resistant varieties is essential for combating the major insects, which requires continuous efforts of breeders and pathologists.

Among the major insects of rice stem borer, brown plant hopper, green leaf hopper, white backed plant hopper, leaf folder, gall midge are most economically important insects and have possessed challenge to the farmers for successful cultivation of rice. Keeping this fact in view, to find out resistant/tolerant indigenous red rice germplasm along with two commercial red rice Kerala varieties against the stem borer and gall midge phenotypic screening was undertaken at two agro-ecological zones i.e. Northern Hills zone and Bastar Plateau of Chhattisgarh.

\section{Materials and Methods}

A total of fifteen red rice genotypes along with two commercial red rice Kerala varieties during Kharif 2016 were raised under natural field conditions at two agro-climatic zones i.e. Northern Hills zone and Bastar Plateau of Chhattisgarh and were screened for stem borer and gall midge resistance/susceptibility.

All the recommended agronomic practices were adopted during the experimentation. For stem borer scoring the total tillers and number of dead hearts at vegetative stage was noted and percent dead hearts was worked out.

$$
\begin{gathered}
\text { No. of dead hearts counted } \\
\% \text { dead hearts }=\text {------------------ x } 100 \\
\text { Total no. of tillers observed }
\end{gathered}
$$

For gallmidge scoring, a total number of tillers and total number of tillers with silver shoot were recorded and the percent tiller infestation was calculated as follows-

$$
\% \text { silver shoot }=\frac{\text { No. of infested tillers }}{\text { Total no. of tillers }}
$$

To check the level of resistance/susceptibility the percentage dead hearts and silver shoot in each entry was converted to 0-9 scale by following the IRRI Standard Evaluation System (SES) for rice and the details are in Table 1.

\section{Results and Discussion}

Resistant varieties play pivotal role in the management of insect pest of any crop as compared to any other control measures. Therefore, fifteen red rice genotypes were screened against stem borer and gall midge.

\section{Phenotypic screening under field condition for stem borer resistance at Ambikapur and Jagdalpur region}

Results of the present study showed that the genotype Dubraj (D: 1251) was found to be resistant with ' 1 ' scale whereas, six genotypes 
were moderately resistant with ' 3 ' scale, eight were moderately susceptible and none of the genotype was found highly resistant or highly susceptible at Northern Hills zone i.e. Ambikapur. The results of Bastar Plateau i.e. Jagdalpur revealed that nine genotypes were highly resistant with ' 0 ' scale, 5 were resistant with ' 1 ' scale whereas only single genotype was found moderately susceptible with ' 5 ' scale for stem borer (Table 2, Fig. 1). These results are in agreement with earlier findings of Elanchezhyan and Arumugiachamy (2015), Sarwar (2012) and Visalakshmi et al., (2014). The screening of red rice genotypes led to identification of some genotypes with natural resistance to stem borer. The resistance in the genotypes may be due to the presence of a strong repellent or a lack of feeding stimulus in the plants and either due to the presence of toxic material or nutritional deficiencies in the plants for the insects.

Table.1 Standard Evaluation System (SES) for stem borer and gall midge

\begin{tabular}{|c|c|c|c|}
\hline Scale & $\begin{array}{c}\text { Damaged plants } \\
\text { (Dead hearts) }\end{array}$ & $\begin{array}{c}\text { Damaged plants } \\
\text { (silver shoots) }\end{array}$ & Reaction \\
\hline 0 & No damage & No damage & Highly resistant (HR) \\
\hline 1 & $1-5 \%$ & Less than 1\% & Resistant (R) \\
\hline 3 & $6-10 \%$ & $1-5 \%$ & Moderately Resistant (MR) \\
\hline 5 & $11-15 \%$ & $6-10 \%$ & Moderately Susceptible (MS) \\
\hline 7 & $16-25 \%$ & $11-25 \%$ & Susceptible (S) \\
\hline 9 & $26 \%$ and above & More than 50\% & Highly Susceptible (HS) \\
\hline
\end{tabular}

Table.2 Reaction of red rice genotypes against stem borer and gall midge at two agro-climatic zone of Chhattisgarh

\begin{tabular}{|l|l|c|c|c|c|}
\hline \multirow{2}{*}{ S. No. } & \multirow{2}{*}{ Name of Accessions } & \multicolumn{4}{|c|}{ Score with reaction } \\
\cline { 3 - 6 } & & \multicolumn{2}{|c|}{ Stem borer } & \multicolumn{2}{c|}{ Gall Midge } \\
\cline { 3 - 6 } & & Ambikapur & Jagdalpur & Ambikapur & Jagdalpur \\
\hline 1 & Dubraj (D:1251) & R & MR & MS & HS \\
\hline 2 & Luchai (L:246) & MR & HR & MS & MS \\
\hline 3 & Mancha (M:1028) & MR & MR & MS & HS \\
\hline 4 & Luchai (L:1099) & MS & HR & MS & MR \\
\hline 5 & Mahipal (M:27A) & MR & MR & MS & HS \\
\hline 6 & Umari (U:CGA:1745 I) & MS & HR & MS & HS \\
\hline 7 & Kekai (K:937 II) & MR & MS & MS & HS \\
\hline 8 & BanthaLuchai (B:2733) & MS & HR & S & S \\
\hline 9 & Mokdo (M:550) & MR & HR & MS & HS \\
\hline 10 & Shrikamal (S:660 I) & MS & HR & MR & MR \\
\hline 11 & Kankadiya (K:1811) & MS & MR & MS & HS \\
\hline 12 & Khuddi (K: 1128 IV) & M & HR & MS & HS \\
\hline 13 & Mahipal (M: 605) & MS & HR & S & HS \\
\hline 14 & Aruna & MS & HR & S & S \\
\hline 15 & Krishnanjana & MR & MR & S & MR \\
\hline
\end{tabular}


Fig.1 Distribution of stem borer and gall midge resistance scale in 15 red rice genotypes

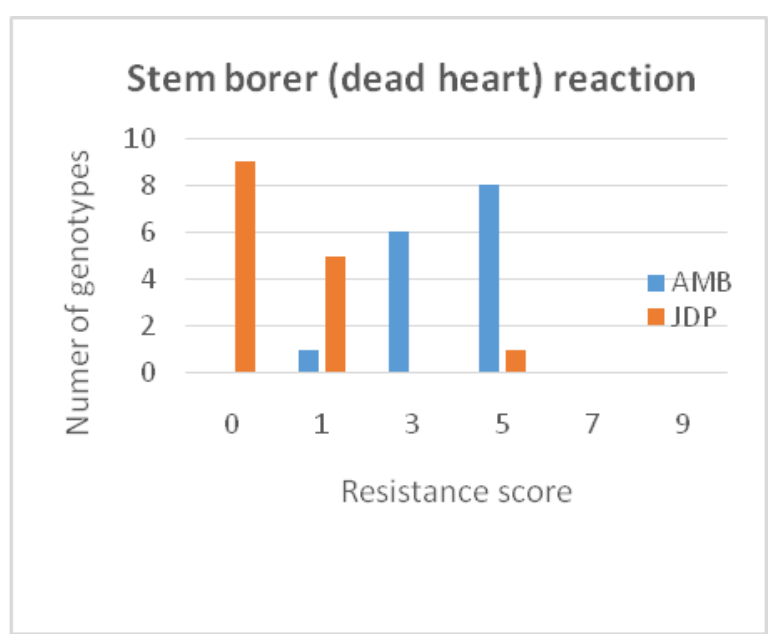

Phenotypic screening under field condition for gall midge resistance at Ambikapur and Jagdalpur region

The field evaluation was done at Ambikapur to study the gall midge resistance. The results revealed that the single genotype i.e. Shrikamal (S: 660 I) was moderately resistant, ten were moderately susceptible and four were found susceptible. Similarly, at Jagdalpur nine genotypes were found highly resistant, three were moderately resistant, one genotype was moderately susceptible and two were found susceptible (Table 2, Fig. 1). These results are in agreement with findings of Ogah et al., (2012) and LU et al., (2013). The concept of host plant resistant is quite old, therefore, the development and use of resistant varieties against insects and to identify pest resistance sources, it is very important to have such type of genetically diverse crop materials.

Considering both the agro-climatic zones the genotypes Dubraj (D: 1251), Mancha (M:1028), Mahipal (M:27 A) and Krishnanjana for stem borer and Shrikamal (S: 660 I) for gall midge exhibited resistance and hence can be developed as varieties or can be used in breeding programme as a source of resistance. Thus, it can be

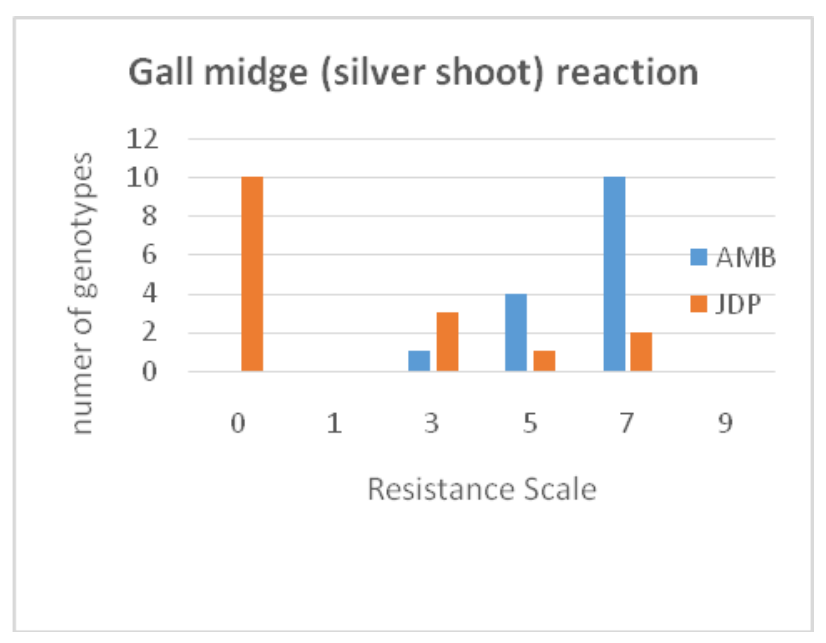

concluded that an understanding of the resistance response of rice germplasm will be useful for the development of efficient utilization of the existing resistance sources for the development of resistance variety because cultivation of insect resistant rice cultivar against these insects is a major component of Integrated Pest Management (IPM) program and highly compatible with other control measures.

\section{Acknowledgement}

The authors are thankful to the Entomology Department of RMD College of Agriculture and Research Station, Ambikapur and SG College of Agriculture and Research Station, Jagdalpur for providing necessary facilities in carrying out the present investigation.

\section{References}

Anonymous, 2014. Socio-economic statistical information about India. INDIASTAT, Ministry of Agriculture, Govt. of India, New Delhi, 1-3.

Anonymous, 2015. Report of Agriculture Department, Chhattisgarh Government. Krishi Diary, Directorate of Extension Services, IGKV, Raipur, p. 5. 
Elanchezhyan, K., and Arumugiachamy, S. 2015. Evaluation of medium duration germplasm against yellow stem borer, Scirpophaga incertulas Walker in rice. Biotic Environment, formerly Insect Environment, 21(2\&3), 38-41.

Jia-shi, L.U., HE, Long-fei; XU, Jing, XU, Chun-yan, LI, Chuang-zhen; WEI, Sumei and SU, Jian-mu. 2013. Identification and Genetic Analysis of Gall Midge Resistance in Rice Germplasm 91-1A2. Rice Science, 20 (1), 73-78

Ogah, E.O., Odebiyi, J.A., Omoloye, A.A. and Nwilene, F.E. 2012. Evaluation of some rice genotypesfor incidence of African rice gall midge and its parasitoid (P. Diplosisae). African Crop Science Journal, 20(2), 137-147.

Sarwar, M., 2012. Management of aromatic rice (Oryza sativa 1.) genotypes using varietal resistance against the prevalence of rice stem borers. Intl. $J$. Agron. Plant. Prod., 3 (8), 295-299.

Visalakshmi, V., Hari Satyanarayna, N., Jyothula D. P. B, Raju, M. R. B. and Ramana Murthy, K. V. 2014. Screening of rice germplasm for resistance to yellow stem borer Scirpophaga incertulas Walker. International Journal of Plant, Animal and Environmental Sciences, 4(1), 129-133.

\section{How to cite this article:}

Mangla Parikh, Bhawana Sharma, Sandeep Bhandarkar, Om Narayan Verma and Ojha, G.C. 2017. Reactions and Resistance Status of Red Rice Genotypes against Stem Borer and Gall Midge under Different Agro-Climatic Zones of Chhattisgarh, India. Int.J.Curr.Microbiol.App.Sci. 6(10): 2044-2048. doi: https://doi.org/10.20546/ijcmas.2017.610.242 